九州大学学術情報リポジトリ

Kyushu University Institutional Repository

Performance and Interrelationship among Several Characters of Pearl Millet (Pennisetum tgphoideum Rich. ) Population

Haryanto, Totok Agung Dwi

Laboratory of Crop Science, Faculty of Agriculture, Kyushu University

Yoshida, Tomohiko

Laboratory of Crop Science, Faculty of Agriculture, Kyushu University

https://doi.org/10.5109/24123

出版情報: 九州大学大学院農学研究院紀要. 41 (1/2)，pp.1-9, 1996-11. Kyushu University バージョン:

権利関係 : 


\title{
Performance and Interrelationship among Several Characters of Pearl Millet (Pennisetum tgphoideum Rich.) Population
}

\author{
Totok Agung Dwi Haryanto and Tomohiko Yoshida
}

\author{
Laboratory of Crop Science, Faculty of Agriculture, \\ Kyushu University, Fukuoka 812-81, Japan \\ (Received July 31, 1996)
}

\begin{abstract}
Information regarding with population performance of pearl millet in Japan is scarce. Objectives of this research were: to evaluate performance of pearl millet population grown in late summer in Japan, to study the correlations and compensatory effects among characters, to determine the direct and indirect effects of characters to seed yield, and to determine the most important character (s) to seed yield. Results showed that the population had wide variability for the character measured. Some characters showed normal distribution. There were significant correlations between pairs of the characters. Seed yield significantly correlated to all of the characters, except mean of the panicle length. There were compensatory effects between several pairs of the characters. Counterbalance phenomena were found in interrelationship among characters. The number of productive panicles may be said as the most important character which influences to seed yield. Selection for high seed yield genotype through number of productive panicles as criterion is possible.
\end{abstract}

\section{INTRODUCTION}

Pearl millet (Pennisetum typhoideum Rich.) is a crop widely grown in arid to semi arid regions (Oendeba et al., 1995), as the main food crop for the native people of Africa (Burton, 1980), the fourth most extensively cultivated cereal, after rice, wheat, and sorghum, in India, and has been grown most extensively as a forage crop in USA (Burton et al., 1995; Degenhart et al., 1995). Information regarding with genetic variability and interrelationship among characters in relation to seed yield of pearl millet is one of the most important factors in planning a successful breeding program in the crop plant. A high level of variability in the population for the characters of interest is required for effective selection (Fehr, 1987). Interrelationship among characters is a guidance in choosing the most important character to select for the higher grain yield.

Coefficient of correlation and path coefficient are statistical analysis tools and have been great deal used for study of interrelationship among characters in many of crop plants. Coefficient of correlation is a measurement of the closeness of the relationship degree or the variability degree between two variables (Steel and Torrie, 1980). Path coefficient analysis is helpful in partitioning the correlation coefficient into its direct and indirect effects, so that the relative contribution of each component characters to yield can be assessed (Mogali and Virupakshappa, 1994).

Many studies were carried out in attempt to study the performance and interrelationship among characters in pearl millet and other crop plants. For example, Yandav (1994) had studied the genetic divergence of Indian and exotic origin pearl millet accessions. Diz et al. (1995) had worked on the defoliation effects and seed yield 
components in pearl millet $x$ elephant grass hybrids. M'Ragwa et al. (1995) had reported the selection response for seedling root length and coleoptyle length in pearl millet. Oendeba et $a l$. (1995) had researched the diversity among African pearl millet landrace populations. Lynch et al. (1995) had studied about vegetative growth index and related traits inheritance in pearl millet. Sagar and Singh (1995) had reported the genotypeenvironment interaction in pearl millet generations. Degenhart et al. (1995) had investigated the forage yield in pearl millet mutant. Variability and intercharacters associations in cashewnut (Sena et al., 1994), in broomgrass (Rath et al., 1994), in deshi cotton (Dedaneya and Pethani, 1994), and in sun-flower (Mogali and Virupakshappa, 1994), had been reported. Yoshida and Sumida (1996) tried mass selection for early heading to grow this crop in late summer after rice harvesting and found that the population selected for early heading had higher grain yield. No information about performance and interrelationship among characters are available in enough, however, for the crop grown in late summer in Japan.

Objectives of the research are: 1). to evaluate performance of several characters of pearl millet population grown in late summer of Japan, 2). to study the correlations and compensatory effects between several characters and seed yield, 3). to determine the direct and indirect effects of several characters in relation to seed yield, and 4). to determine the most important character (s) to seed yield in pearl millet.

\section{MATERIALS AND METHODS}

A heterozygous population of three hundred and ten plants was grown in Experimental Farm of Faculty of Agriculture, Kyushu University, Fukuoka during middle of August 1995 to last of November in 1995. Seeds were planted August, 10 in four rows and thinned after 2 weeks of emergence to $15 \times 60 \mathrm{~cm}^{\prime}$ between and within rows. $5 \mathrm{gm}^{-2}$ each of $\mathrm{N}: \mathrm{P}_{2} \mathrm{O}_{5}: \mathrm{K}_{2} \mathrm{O}$ were fertilized at the date of planting. All of plants were subjected for total of ten characters observation. Plant height $(\mathrm{cm})$, total number of tillers, number of productive tillers, total number of panicles, and number of productive panicles per plant were characters measured before harvesting. Mean of panicle length $(\mathrm{cm})$, mean of panicle weight $(\mathrm{g})$, mean of seed weight per panicle $(\mathrm{g})$, 100-seed weight $(\mathrm{g})$, and total seed weight (yield) per plant were characters evaluated after harvesting. Germination test was conducted to seeds of the highest $10 \%$ and the lowest $10 \%$ values of population for each of character evaluated.

Each of data set of the all characters evaluated was subjected for Lilifors' s normality distribution assessing (Conover, 1980). Analysis for coefficient of correlation and path coefficient were referred to Steel and Torrie (1980) and Li (1975). Causal relationship between several characters and yield of pearl millet in a path diagram is as shown in Figure 1. Minimum, mean, maximum, variance, coefficient of variation, and standard error values were counted. Original population was early maturing and short stature "ICVM83074", kindly provided by Dr. C.T. Hash of ICRISAT (India), and was later seedincreased by open pollinating in several seasons including May and August sowing. 


\section{RESULTS AND DISCUSSION}

\section{Population performances}

Population performance including minimum, mean, maximum, variance, coefficient of variation, and standard error values for each of characters are shown in Table 1. The frequency distributions are shown in Figure 2. In general, the population widely varied for the characters measured. These are expressed by high value of variances, especially for plant height, mean of panicle length, mean of panicle weight, seed weight per panicle, and seed yield per plant. The variance values for all characters were shifted between 0.067 and 558.999. The highest varied character was plant height and the lowest varied one was 100 -seed weight. The wide variability was also expressed by high value of coefficient variation, higher than 20 percent, for most of characters. The coefficient of variation value was shifted between 21.923 and 100 percent. The high level of variability is an important factor in the crop improvement program. It determines the selection effectiveness and the magnitude of selection response can be hoped.

The importance of assessing the population mean value and maximum value is that the effective selection in a population results in a change in the population mean value for character evaluated.

Figure 2 showed that plant height, total number of tillers, mean of panicle length, mean of panicle weight, and 100-seed weight per plant were characters normally distributed. The figure also represented the minimum, mean, maximum value for characters, and the level of variability.

Mean performance of the highest 10 percent and lowest 10 percent values of population for all characters and the mean of each percent of germination are shown in

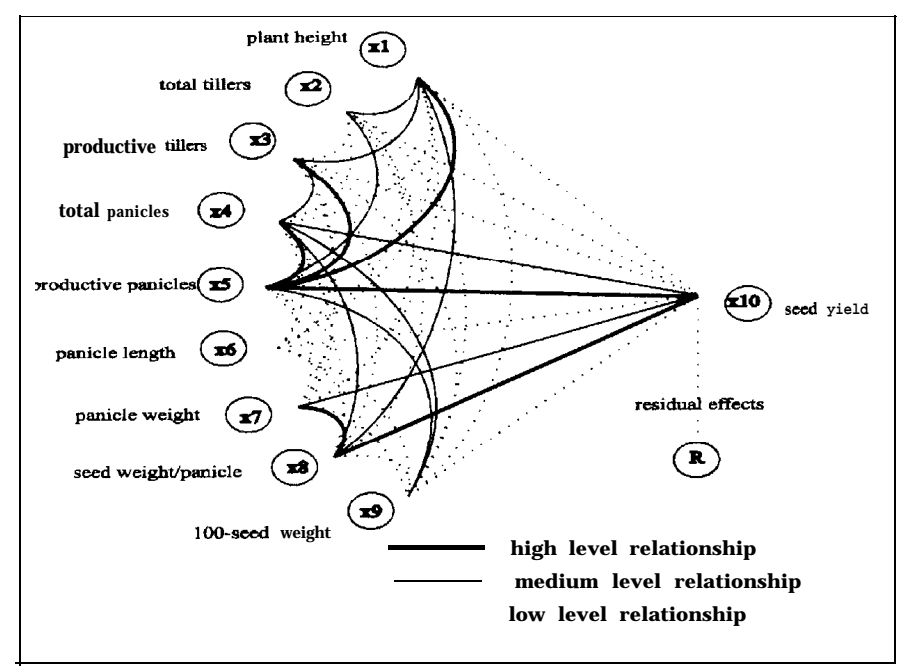

Fig. 1. Diagram of path of nine characters $(x 1-x 9)$ to the seed yield $(x 10)$ of pearl millet. Stright lines show dirrect effects and curve lines show indirect effets for each characters to the seed yield. 


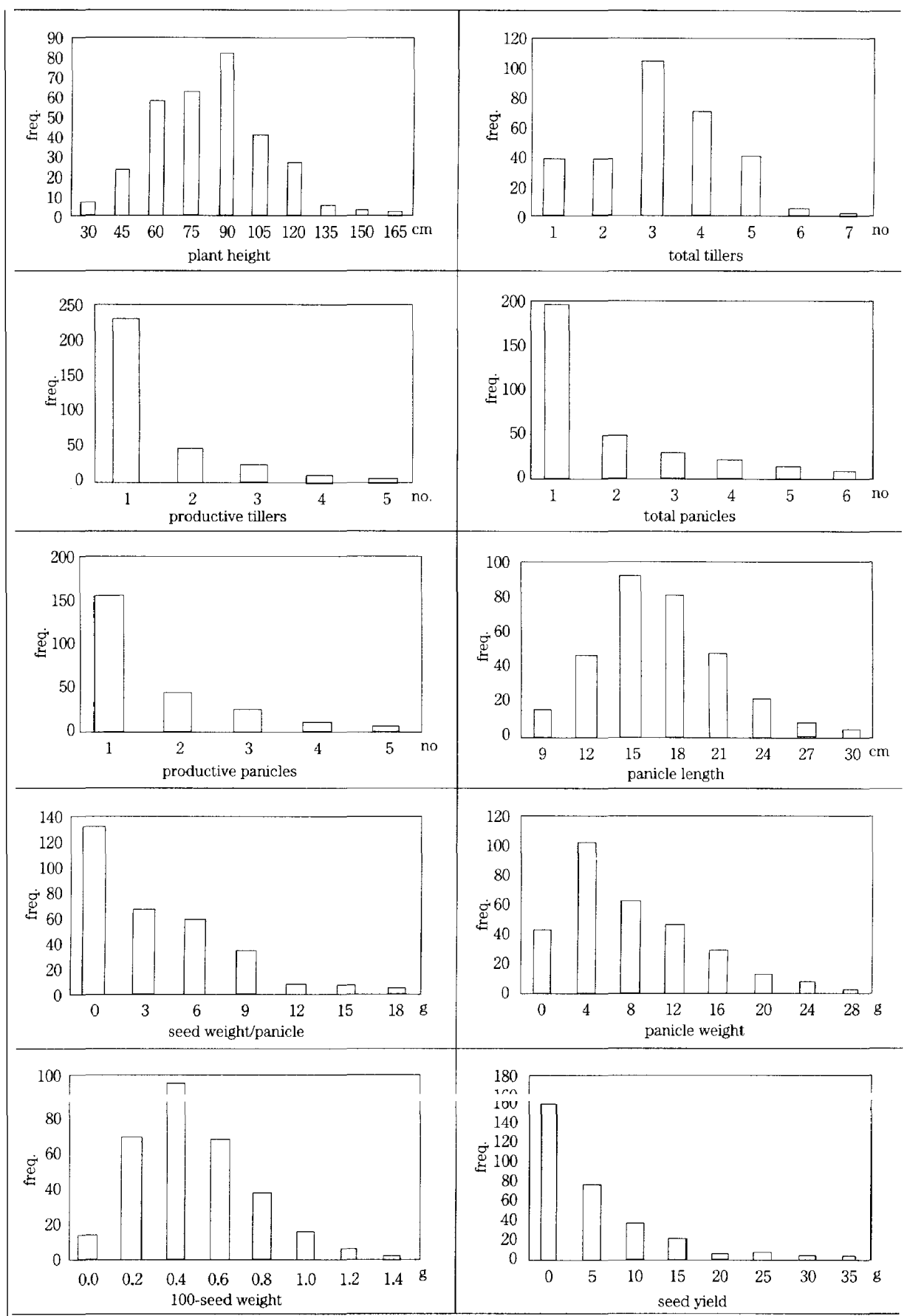

Fig. 2. Frequency distribution of nine characters of pearl millet population. 
Table 1. Performance of nine characters of pearl millet population.

\begin{tabular}{lrrrrrr} 
Characters & $\begin{array}{l}\text { Minimum } \\
\text { value }\end{array}$ & $\begin{array}{l}\text { Maximum } \\
\text { value }\end{array}$ & $\begin{array}{l}\text { Mean } \\
\text { value }\end{array}$ & Variance & $\begin{array}{l}\text { coeff. of } \\
\text { variation (\%) }\end{array}$ & $\begin{array}{l}\text { standard } \\
\text { error }\end{array}$ \\
\hline Plant height (cm) & 30.00 & 165.00 & 89.429 & 558.999 & 26.438 & 1.34 \\
Total tillers & 1.00 & 7.00 & 3.201 & 1.667 & 40.340 & 0.07 \\
Prod. tillers & 1.00 & 5.00 & 1.401 & 0.592 & 54.907 & 0.04 \\
Total panicles & 1.00 & 9.00 & 1.771 & 1.665 & 72.893 & 0.07 \\
Prod. panicles & 1.00 & 5.00 & 1.398 & 0.617 & 56.183 & 0.07 \\
Panicle length (cm) & 9.87 & 31.00 & 18.426 & 16.318 & 21.923 & 0.23 \\
Panicle weight (g) & 1.10 & 31.05 & 9.616 & 35.328 & 61.812 & 0.34 \\
Seed weight/pcl (g) & 0.01 & 19.36 & 4.733 & 16.237 & 85.145 & 0.23 \\
100-seed weight (g) & 0.12 & 1.51 & 0.569 & 0.067 & 45.451 & 0.02 \\
Seed yield/plant (g) & 0.01 & 47.21 & 6.859 & 53.649 & 100.000 & 0.42 \\
\hline
\end{tabular}

Table 2. Mean performance of the highest 10 percent and the lowest 10 percent of population and the percent of germination.

\begin{tabular}{lcccc}
\hline Characters & $\begin{array}{c}\text { the highest } \\
10 \text { percent }\end{array}$ & $\begin{array}{l}\text { germination } \\
\text { mean (\%) }\end{array}$ & $\begin{array}{c}\text { the lowest } \\
10 \text { percent }\end{array}$ & $\begin{array}{l}\text { germination } \\
\text { mean (\%) }\end{array}$ \\
\hline Plant height & $132.6 \mathrm{~cm}$ & 100.0 & $51.2 \mathrm{~cm}$ & 100.0 \\
Total tillers & 5.3 & 93.0 & 1.0 & 76.0 \\
Prod. tillers & 3.3 & 92.8 & 1.0 & 76.0 \\
Total panicles & 4.9 & 90.0 & 1.0 & 76.0 \\
Prod. panicles & 3.4 & 96.0 & 1.0 & 76.0 \\
Panicle length & $26.3 \mathrm{~cm}$ & 96.0 & $12.1 \mathrm{~cm}$ & 44.0 \\
Panicle weight & $22.1 \mathrm{~g}$ & 98.6 & $2.3 \mathrm{~g}$ & 95.0 \\
Seed weight/panicle & $13.2 \mathrm{~g}$ & 100.0 & $0.2 \mathrm{~g}$ & 62.2 \\
100-seed weight & $1.1 \mathrm{~g}$ & 92.0 & $0.2 \mathrm{~g}$ & 24.0 \\
Seed yield/plant & $24.1 \mathrm{~g}$ & 94.0 & $0.2 \mathrm{~g}$ & 52.2
\end{tabular}

Table 2. It was seen that percent of germination of the highest 10 percent of population was shifted between 90 and 100 percent, and averaged 95.24 percent. The lowest 10 percent of population, however, was shifted between 24 and 100 percent, and averaged 67.20 percent. The highest 10 percent of population, therefore, performed 28.04 percent of germination higher than the lowest 10 percent of population for all character

\section{Interrelationship among characters}

Coefficient of correlation among characters evaluated are represented in Table 3. Plant height had significant positive correlations to all of characters evaluated except number of productive tillers, number of productive panicles, and mean of panicle length 
Table 3. Coefficient of correlation among nine characters of pearl millet population.

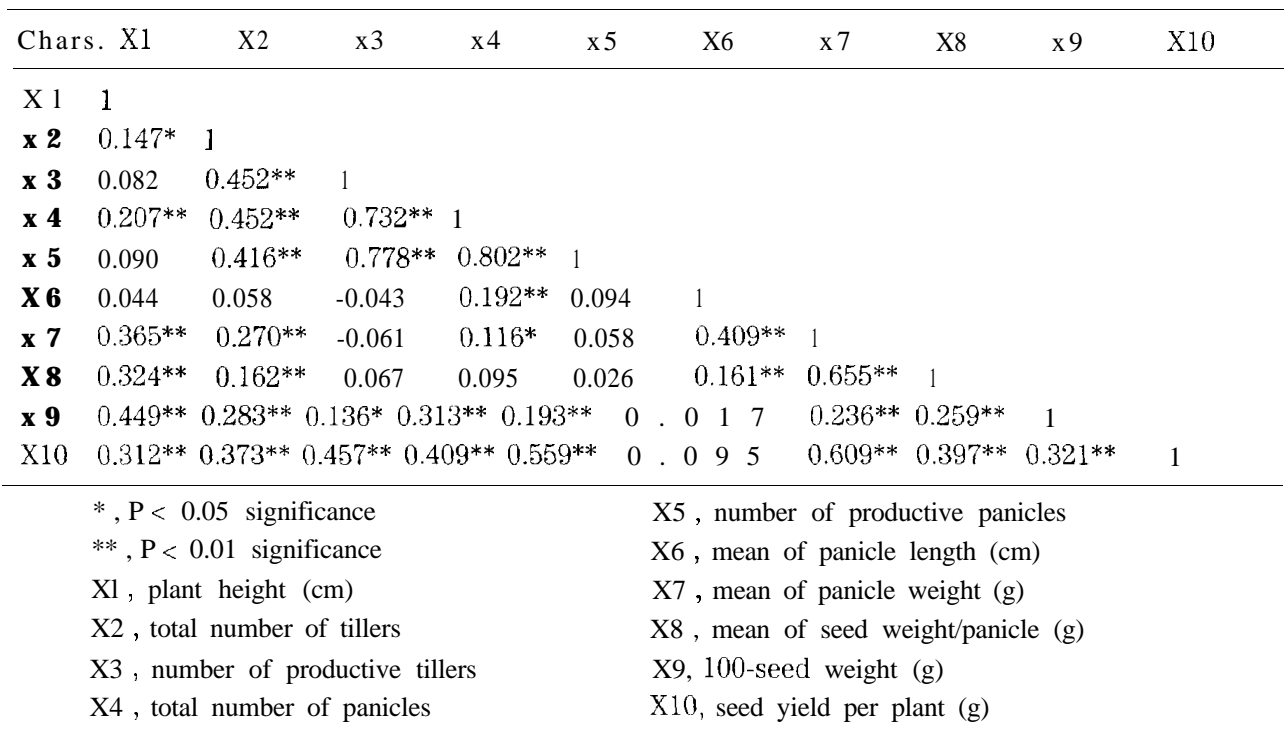

per plant. Total number of tillers per plant had significant positive correlations to all of characters evaluated except mean of panicle length.

Number of productive tillers per plant had significant positive correlations to the total number of tillers, total number of panicles, number of productive panicles, 100-seed weight, and seed yield, but no significant correlations to the plant height and mean of seed weight per panicle. Total number of panicles per plant had significant positive correlations to all of characters evaluated, except mean of seed weight per panicle. The number of productive panicles per plant had significant positive correlations to all of characters evaluated, except plant height, mean of panicle length, mean of panicle weight, and mean of seed weight per panicle. Mean of panicle length per plant had significant positive correlations to total number of panicles, mean of panicle weight, and mean of seed weight per panicle, but no significant correlations to plant height, total number of tillers, 100-seed weight, and seed yield. Mean of panicle weight had significant positive correlations to all of characters evaluated, except number of productive panicles, and number of productive tillers. Mean of seed weight per panicle had significant positive correlation to all of characters evaluated, except number of productive tillers, total number of panicles, and number of productive panicles per plant. Seed yield and 100-seed weight had significant positive correlations to all of characters evaluated except mean of panicle length.

The highest value of coefficient correlation (0.802) was correlation between total number of panicles and number of productive panicles, followed by correlation between number of productive tillers and number of productive panicles (0.778), and correlation between number of productive tillers and total number of tillers (0.732). The most 
correlated character to the seed yield was the mean of panicle weight, followed by number of productive panicles, number of productive tillers, total number of panicles, and seed weight per panicle. Ouendeba et al. (1995) had reported that number of productive tillers per plant showed the strongest association to the grain yield of pearl millet.

Negative correlations were found between number of productive tillers and mean of panicle length, and between number of productive tillers and mean of panicle weight, confirm to Ouendeba et al. (1995). Negative correlation indicates the compensatory effects between characters. It means that the increasing of the productive number of tillers may be followed by decreasing of panicle length and panicle weight. In contrary, the increasing of panicle length and/or panicle weight may result in the decreasing of productive number of tillers.

Positive correlation in many of characters relationship interprets to the similarity of direction of the trend association. It also indicates that compensatory effect was not found and competition among the characters may be ignored. Confirming with these results, the positive correlations of the primary panicles per plant, seed weight per panicle, and 100-seed weight to the seed yield per plant of pearl millet, in the low-yield situation, were reported by Diz et al. (1995).

Result of path coefficient analysis for each characters to the seed yield are shown in Table 4. Sum of the direct effects (path coefficient) of each character, underlined, and indirect effects through other characters results the correlation between the character and seed yield. It seemed that each of the plant height, total number of tillers, and number of productive tillers per plant was the character which negatively had direct effects to the yield. Other characters had positive direct effects to the yield. Diz et al. (1995) had reported that the positive direct effect of the primary panicle per plant, seeds per panicle, and 100-seed weight to the seed yield of pearl millet and relatively low value of indirect effect through other yield components, led to the positive correlations among these yield components to the yield.

Table 4. Path coefficient between several characters and seed yield of pearl millet population (for X1- X9, see Table 3).

\begin{tabular}{|c|c|c|c|c|c|c|c|c|c|c|}
\hline & $\mathrm{X} 1$ & $x 2$ & $\times 3$ & $\mathrm{x} 4$ & X5 & X6 & $\times 7$ & $\mathrm{X} 8$ & X9 & \\
\hline $\mathrm{X} 1$ & -0.026 & -0.009 & -0.008 & -0.021 & 0.583 & 0.002 & 0.038 & 0.231 & 0.005 & 0.312 \\
\hline $\mathrm{X} 2$ & -0.003 & $\underline{-0.046}$ & -0.038 & 0.031 & 0.256 & 0.005 & 0.059 & 0.089 & 0.003 & 0.373 \\
\hline X3 & -0.001 & -0.022 & $\underline{-0.071}$ & 0.033 & 0.445 & 0.002 & 0.002 & 0.068 & -0.001 & 0.457 \\
\hline $\mathrm{X} 4$ & -0.034 & -0.021 & -0.053 & 0.003 & 0.435 & -0.006 & 0.011 & 0.008 & 0.002 & 0.409 \\
\hline X5 & -0.002 & -0.022 & -0.058 & 0.023 & 0.563 & -0.003 & 0.030 & 0.026 & 0.001 & 0.559 \\
\hline X6 & -0.001 & 0.009 & -0.002 & 0.002 & -0.035 & $\underline{0.045}$ & -0.125 & 0.198 & 0.001 & 0.095 \\
\hline$\times 7$ & -0.011 & -0.010 & -0.003 & 0.003 & -0.018 & 0.021 & $\underline{0.153}$ & 0.474 & 0.001 & 0.609 \\
\hline $\mathrm{X} 8$ & -0.009 & 0.002 & 0.001 & -0.005 & -0.003 & 0.013 & -0.152 & 0.548 & 0.005 & 0.3970 \\
\hline$\times 9$ & -0.014 & -0.008 & -0.011 & 0.015 & 0.107 & 0.001 & 0.035 & 0.151 & $\underline{0.011}$ & .321 \\
\hline
\end{tabular}

Direct effects shown in main diagonal (underlined) for each character and indirect, effets through the other characters to seed yield are shown in the same line. 
Although direct effects of the plant height $(-0.026)$, total number of tillers $(-0.046)$, and number of productive tillers $(-0.071)$ to the seed yield were negative, however, counterbalanced by positive high values of indirect effects through number of productive panicles character; i. e., $0.583,0.256$, and 0.445 , respectively, resulted positive correlation to the seed yield. These reflect to the possibility of selecting for the short genotype, without decreasing the seed yield, when the genotype has high number of productive panicles that contributes to the seed yield indirectly.

Relatively high value of direct effects of mean of seed weight per panicle to the yield (0.548) and counterbalanced negative direct effects through other characters resulted in decreasing its correlation to the seed yield (0.397). Low value of direct effects of mean of panicle weight to the seed yield (0.153), counterbalanced by relative low value of indirect effects through any other characters and high value of indirect effect through mean of seed weight per panicle (0.474) resulted in high value of its correlation to the seed yield (0.609). Productive number of panicles per plant showed the highest value of path coefficient (0.563). Relatively low counterbalance through other characters resulted in high value of its positive correlation to the seed yield (0.559). It means that productive number of panicles per plant is the most influential character to the seed yield by the strong direct effects and correlation to the seed yield. Indirect selection for high seed yield genotype through the number of productive panicles character as a criterion of selection, therefore, is possible.

\section{REFERENCES}

Burton, G. W. 1980 Pearl millet. In "Hybridization of Crop Plants", ed. by W. R. Fehr and H. H. Hadley, Am. Soc. of Agon. Crop Sci Soc. of America, Madison, pp. 457-469

Burton, G. W. and J. P. Wilson 1995 Identification and transfer of heterotic chromosome blocks for forage yild in short-day exotic pearl millet landraces. Crop Sci., 35: 1184-1 187

Conover, W. J. 1980 Practical Non-parametric Statistic. John Wiley \& Sons. Inc. Singapore

Dedaniya, A. D. and K. V. Pethani 1994 Genetic variability, correlations and path analysis in deshi cotton (Gossypium arboreum L.). Indian J. Genet., 54(3): 229-234

Degenhart, N. R., B.K. Werner and G. W. Burton 1995 Forage yield and quality of brown mid-rib mutant in pearl millet. Crop Sci., 35: 986-988

Diz, D. A., S. C. Schanck and D. S. Wofford 1995 Defoliation effects and seed yield components in pearl millet $\mathbf{x}$ elephantgrass hybrids. Agron. J., 87: 56-62

Fehr, W. R. 1987 Principles of Cultivar Development. Vol. 1. Collier Macmillan Publisher, London, 536 pp.

Li, C. C. 1975 Path Analysis: A primer. Booxwood Press, Pacific Grove. CA

Mogali, S. C. and K. Virupakshappa 1994 Intercharacter association and path coefficient analysis in sunflower (Helianthus annuus L.). Indian J. Genet., 54 (4): 366-370

M' Ragwa, L. R. F., C. E. Watson, Jr. and L. M. Gourley 1995 Selection response for seedling root length and coleoptile length in pearl millet. Crop Sci., 35: 1032-1036

Ouendeba, B., G.Ejeta, W. W. Hanna and A. K. Kumar 1995 Diversity among African pearl millet landrace populations. Crop Sci., 35: 919-924

Rath, S., P. N. Jagadev and A. K. Patnaik 1994 Genetic variability and character association in Broomgrass (Thysanolaena maxima Roxb.). Indian J. Genet., 54(3): 300-303

Sagar, P. and R. Singh 1995 Analysis of genotype-environment interaction in pearl millet generations. Indian J. Genet., $\mathbf{5 5}(1)$ : 31-35

Sena, D. K., P. C. Lenka, P. N. Jagadev and S. Beura 1994 Genetic variability and character association in 
cashewnut (Anacardium occidentale L.). Indian J. Genet., 54(3): 304-309

Steel, R. G., and.J. H. Torrie 1980 Principles and Procedures of Statistics. McGraw-Hill Inc., London

Yadav, 0. P. 1994 Genetic divergence in pearl millet accessions of Indian and exotic origin. Indian J. Genet., $\mathbf{5 4}(1): 89-93$

Yoshida, T. and K. Sumida 1996 Mass selection and grain yield of improved population in pearl millet (Pennisetum typhoideum Rich.). Jpn. J. Crop Sci., 65(1): 58-62 